\title{
IMPROVING STUDENT ACHIEVEMENT BY USING INTERACTIVE LEARNING MODEL OF IPS LESSON IN NATURAL APPEARANCE AT THE FIRST GRADE STUDENTS OF SD NEGERI 43 SIGUNTUR IN ACADEMIC YEAR 2015/2016
}

\author{
YUSPI
}

Volume 1 Nomor 1

JIPS ISSN: 2579-5449

\begin{abstract}
The purpose of this study is to prove that the use of the environment around the school to enhance students' understanding of the events of Islamic religious education in students of Class I V In S D Affairs No. 43 Siguntur Young.

This study uses a class action approach. The study population was taken of all students in grade IV, the data collection techniques used artificial teacher learning achievement test. Actions performed a total of two cycles. Data analysis techniques used analysis of the percentage of change in the results of the evaluation study before and after tutoring services with peer tutors. Thus there is an increasing mastery learning students from the first cycle to the second cycle. Based on the above, it can be made a conclusion as follows: "Improve Student Achievement 43 Siguntur Young Elementary School Using

IPS About Appearance Semester 1 Academic Year 2015/2016"

In the pre-study enrollment who did not complete the following study is very high. After the implementation of the learning improvement in Cycle 1 appears once improving student learning outcomes at $70 \%, 16$ students have been completed and 7 students are still unresolved. In cycle 2 had peninkatan significantly by $88 \%$.

Based on the description and discussion of the above results begin to cycle 1 to cycle 2 regarding the use of interactive learning model, can the authors conclude that: 1) By using interactive learning, was able to improve student achievement Elementary School fourth grade No. 43 Siguntur Young on the material of natural appearance. 2) Through interactive learning, students can be more active in learning activities, particularly in social studies.
\end{abstract} Interactive Learning Model Lesson In Nature

Keywords: model, interactive, learning 


\section{TINGKATKAN PRESTASI BELAJAR SISWA SD NEGERI 43 SIGUNTUR MUDA DENGAN MENGGUNAKAN MODEL PEMBELAJARAN INTERAKTIF DALAM MATA PELAJARAN IPS TENTANG KENAMPAKAN ALAM SEMESTER 1 TAHUN PELAJARAN 2015/2016}

\begin{abstract}
Tujuan penelitian ini adalah untuk membuktikan bahwa dengan pemanfaatan lingkungan sekitar sekolah dapat meningkatkan pemahaman siswa akan peristiwa pendidikan agama islam pada siswa Kelas IV Di SD Negeri No. 43 Siguntur Muda.

Penelitian ini menggunakan pendekatan tindakan kelas. Populasi penelitian diambil semua siswa kelas IV, Teknik pengumpulan data digunakan tes prestasi belajar buatan guru. Tindakan dilakukan sebanyak dua siklus. Teknik analisis data digunakan analisis persentase dari perubahan hasil evaluasi belajar sebelum dan setelah dilakukan layanan bimbingan belajar dengan tutor sebaya. Dengan demikian terdapat peningkatan ketuntasan belajar siswa dari siklus I ke siklus II. Berdasarkan keterangan di atas maka dapat dibuat suatu kesimpulan sebagai berikut : " Tingkatkan Prestasi Belajar Siswa SD Negeri 43 Siguntur Muda Dengan Menggunakan Model Pembelajaran Interaktif Dalam Mata Pelajaran IPS
\end{abstract}

ABSTRAK
Kata Kunci: model, pembelajaran, interaktif

\section{PENDAHULUAN}

Latar Belakang Masalah, Dalam proses belajar mengajar guru menjadi pemeran utama dalam menciptakan situasi interaktif yang edukatif, yakni interaksi antara guru dengan siswa, siswa dengan siswa dan denga sumber pembelajaran dalam menunjang tercapainya tujuan belajar. Untuk terwujudnya proses belajar mengajar seperti itu sudah tentu menuntut upaya guru
Tentang Kenampakan Alam Semester 1 Tahun Pelajaran 2015/2016 “

Pada pra pembelajaran jumlah siswa yang tidak tuntas dalam mengikuti pembelajaran sangat tinggi. Setelah dilaksanakan perbaikan pembelajaran pada Siklus 1 nampak sekali peningkatan hasil belajar siswa yaitu sebesar $70 \%, 16$ siswa sudah tuntas dan 7 siswa masih belum tuntas. Pada siklus 2 mengalami peninkatan secara signifikan sebesar $88 \%$.

Berdasarkan uraian pembahasan dan hasil penelitian di atas mulai Siklus 1 sampai siklus 2 mengenai penggunaan model pembelajaran interaktif, dapat penulis simpulkan bahwa: 1) Dengan menggunakan pembelajaran interaktif, ternyata mampu meningkatkan prestasi belajar siswa kelas IV SD Negeri No. 43 Siguntur Muda pada materi tentang kenampakan alam. 2) Melalui pembelajaran interaktif, siswa dapat lebih aktif dalam kegiatan belajar, terutama pada mata pelajaran IPS.

untuk mengaktualisasikan kompetensinya secara professional, utamanya aspek metodologis.

IPS sebagai salah satu bidang studi yang memiliki tujuan membekali siswa untuk mengembangkan penalarannya disamping aspek nilai dan moral, banyak memuat materi social bersifat hapalan sehingga pengetahuan dan informasi yang diterima siswa sebatas produk 
hapalan. Sifat pelajaran IPS tersebut membawa konsekuensi terhadap proses belajar mengajar yang didominasi oleh pendekatan ekspositoris, terutama guru menggunakan metode ceramah sedangkan siswa kurang terlibat atau cenderung pasif. Dalam metode ceramah terjadi dialog imperaktif. Padahal, dalam proses belajar mengajar keterlibatan siswa harus secara totalitas, artinya melibatkan pikiran, penglihatan, pendengaran, dan psikomoto (keterampilan, salah satunya sambil menulis). Jadi, dalam proses belajar mengajar, seorang guru harus mengajak siswa untuk mendengarkan, menyajikan media yang dapat dilihat, memberi kesempatan untuk menulis dan mengajukan pertanyaan atau tanggpan sehinga terjadi dialog kreatif yang menunjukkan proses belajar mengajar yang interaktif. Situasi belajar seperti ini dapat tercipta melalui penggunaan pendekatan partisipatoris.

Proses belajar mengajar mempunyai makna dan pengertian yang lebih luas dari pada pengertian mengajar, karena didalamnya tersirat satu kesatuan kegiatan yang tidak terpisahkan antara siswa yang belajar dna guru yang mengajar, yang terjalin dalam bentuk interaksi edukatif. Peran guru dalam pembelajarn IPS mempunyai hubungan erat dengan cara mengaktifkan siswa dalam belajar, terutama dalam proses pengembangan keterampilannya. Pengembangan keterampilan yang harus dimiliki siswa adalah keterampilan berfikir, keterampilan social dan keterampilan praktis. Keterampilan berfikir dikembangkan untuk melatih siswa berfikir logis dan sistematis melalui proses belajar mengajar dengan model pengembangan berfikir kritis, keterampilan social dan praktis melalui model dialog kreatif.Ketiga keterampilan tersebut dapat dikembangkan dalam situasi belajar mengajar yang interaktif antara guru dengan siswa dan siswa dengan siswa.

Permasalahan yang muncul di sekolah saat melaksanakan pembelajaran siswa dalam bidang IPS adalah kurangnya motivasi dari diri siswa dalam mengikuti proses belajar mengajar. Mereka kurang serius dalam memfokuskan diri mengikuti materi pembelajaran IPS.Hal ini muncul karena dalam pelaksanaan belajar mengajar guru lebih sering menggunakan buku sebagai sumber belajar, dimana guru hanya menggunakan metode ceramah saja dalam menjelaskan materi pembelajaran IPS.Tidak adanya media peraga atau contoh gambar yang merupakan sarana pengetahuan nyata bagi siswa.

Berdasarkan hasil observasi dan informasi yang diberikan oleh guru di SDN Randusari, khususnya kelas IV terdapat permasalahan yang dihadapi oleh siswa yaitu kurangnya motivasi dari diri siswa dalam mengikuti proses belajar mengajar mata pelajaran IPS, pernyataan tersebut didasarkan pula pada hasil nilai ulangan harian siswa pada mata pelajaran IPS yang cukup rendah dan daya serap siswa secara klasikal masih dibawah standar minimum yaitu $75 \%$. Secara rinci dari 27 siswa kelas IV di SDN No. 43 Siguntur Muda yang mendapat nilai 80 adalah 3 siswa (11\%), yang mendapat nilai 70 sebanyak 10 siswa (35\%), yang mendapat nilai 60 sebanyak 10 siswa (38\%), yang mendapat nilai 50 sebanyak 4 siswa (14\%). Fakta ini menunjukkan bahwa siswa SDN No. 43 Siguntur Muda belum mencapai ketuntasan belajar pada mata pelajaran IPS.

Setelah kegiatan pembelajaran selesai peneliti mengadakan diskusi teman sejawat, hasil diskusi dengan teman sejawat ditemukan beberapa masalah yang terjadi dalam proses belajar mengajar, yaitu: Kurangnya interaksi antara guru dan siswa. Penguasaan guru tentang metode pengajaran masih berada dibawah standar. Siswa cenderung pasif dan kurangnya motivasi siswa. Metode yang digunakan dalam mengajar hanya ceramah. Siswa cenderung menghafal bukan memahami materi pelajaran.

Terkait dengan yang melatar belakangi pembahasan di atas, maka penulis memilih judul

"Tingkatkan Prestasi Belajar Siswa SD Negeri 43 Siguntur Muda Dengan Menggunakan Model Pembelajaran Interaktif Dalam Mata Pelajaran IPS Tentang Kenampakan Alam Semester 1 Tahun Pelajaran 2015/2016".

Berdasarkan uraian di atas, maka rumusan masalah dalam penelitian ini adalah: Bagaimanakah penggunaan mode pembelajaran interaktif pada materi tentang kenampakan alam 
untuk meningkatkan prestasi belajar siswa kelas IV SDN No. 43 Siguntur Muda?

\begin{tabular}{llr}
\multicolumn{1}{c}{ Tujuan } & Penelitian & Perbaikan \\
Pembelajaran & \multicolumn{1}{c}{ Tindakan } & perbaikan \\
pembelajaran yang & dilaksanakan & dengan \\
berlandaskan kaidah PTK ini bertujuan & sebagai
\end{tabular}

berikut: Dengan penggunaan model pembelajaran interaktif dalam materi tentang kenampakan alam dapat meningkatkan prestasi belajar siswa kelas IV SDN No. 43 Siguntur Muda.

\section{PELAKSANAAN PERBAIKAN PEMBELAJARAN}

Tempat yang digunakan untuk melaksanakan penelitian ini adalah SD Negeri No. 43 Siguntur Muda Kecamatan Koto XI Tarusan.

Waktu yang digunakan peneliti dalam melaksanakan penelitian tindakan kelas ini selama 2 siklus, yaitu pada tanggal 15 Juli 2016 (Siklus 1) dan 22 Agustus 2016 (Siklus 2). Mata pelajaran yang diteliti adalah Ilmu Pengetahuan Sosial dengan materi Kenampakan Alam bagi Kelas IV Semester I SD Negeri No. 43 Siguntur Muda Tahun Pelajaran 2015/2016.

Subjek Penelitiannya adalah siswa SD Negeri No. 43 Siguntur Muda kelas IV B yang berjumlah 23 siswa, terdiri dari 15 siswa lakilaki dan 8 siswa perempuan. Karakteristik siswa kelas IV B SD Negeri No. 43 Siguntur Muda Tahun Pelajaran 2015/2016 ini sangat heterogen, di kelas IV ini tingkat kecerdasan siswa tidak merata.

Rencana perbaikan pembelajaran yang peneliti susun antara lain meliputi: Mengadakan Tanya jawab dan diskusi tentang kenampakan alam. Siswa berdiskusi dan melakukan Tanya jawab tentang kenampakan alam.

Adapun pelaksanaan dari rencana pembelajaran antara lain sebagai berikut: Guru menjelaskan materi dengan melakukan Tanya jawab dengan siswa. Membimbing siswa dalam mengerjakan LKS. Membahas LKS untuk mengukur kemampuan siswa dalam menerima penjelasan guru.

Dalam melaksanakan perbaikan pembelajaran ini kami dibantu oleh rekan sejawat yang bertindak sebagai pengamat yaitu Ibu Ruchayati. Dengan demikian akan diperoleh sampel data yang memang sangat kami butuhkan dalam mengadakan perbaikan pembelajaran ini.
Agar pengamatan ini dapat berjalan dengan baik maka kami memulai dari kesepakatan antara pengamat dengan peneliti, hal ini bertujuan agar pengamatan yang dilakukan lebih terarah pada masalah yang akan diamati.

Beberapa aspek yang diamati antara lain: Menjelaskan konsep kenampakan alam. Memimpin diskusi kelompok. Membimbing siswa berdiskusi. Menarik kesimpulan.

Kegiatan pada siklus 1 ini merupakan refleksi yang akan kami gunakan dalam melihat kekurangan dan kelebihan yang mungkin timbul pada perbaikan pembelajaran, sehingga dapat kami temukan beberapa kekuatan dan kelemahan pada diri peneliti. Antara lain:

KEKUATAN :

Dengan mengadakan perbaikan pembelajaran ini peneliti bisa lebih rinci dalam melihat permasalahan yang sering timbul pada pembelajaran pada umumnya, maka peneliti juga bisa segera membuat rencana perbaikan yang bisa meminimalkan masalah yang ada.

\section{KELEMAHAN :}

Pada saat ini ternyata penelitian yang dilakukan oleh peneliti jarang tidak bisa diakui keabsahannya, karena penelitian ini dilakukan dalam skala yang sempit (hanya pada kelompokkelompok tertentu).

SIKLUS II, Rencana, Pada pelakasanaan pembelajaran siklus 1 , ternyata hasil evaluasi belajar siswa menunjukkan bahwa pemahaman tentang kenampakan alam masih kurang untuk itu peneliti membuat rencana perbaikan pembelajaran yang sesuai dengan tujuan perbaikan pembelajaran yang telah ditetapkan.

Berdasarkan factor-faktor penyebab kurang berhasilnya pembelajaran IPS yang telah 
dilaksanakan maka peneliti merancang rencana secara umum dalam melaksanakan perbaikan pembelajaran materi diantaranya sebagai berikut: Mengadakan dialog dengan siswa yang membahas tentang kenampakan alam yang ada disekitar. Memberikan tugas kelompok yang berupa lembar kerja kelompok, sehingga peneliti dapat mengukur kemampuan siswa dalam memahami pembelajaran. Menggunakan metode pembelajaran yang bervariasi yaitu metode ceramah, metode Tanya jawab, presentasi dan pemberian tugas secara kelompok.

Adapun tahapan-tahapan perencanaan perbaikan pembelajaran sebagai berikut: Membuat rencana perbaikan pembelajaran secara tertulis yang berisi langkah-langkah pelaksanaan pembelajaran yang sekiranya siswa dapat dengan mudah mengikuti pembelajaran. Menyiapkan lembar observasi yang merupakan hasil kesepakatan antara peneliti dan teman sejawat yang bertindak sebagai selaku pengamat. Membuat lembar kerja kelompok untuk mengetahui tingkat keberhasilan pembelajaran siswa.

Dalam pelaksanaan pembelajaran harus memperhatikan beberapa hal terutama tujuan yang hendak dicapai. Sedangkan langkahlangkah perbaikan pembelajaran yang akan dilaksanakan yaitu: Mengisi LKS yang sudah disediakan. Mendeskripsikan kenampakan alam dengan kalimat runtut. Mengadakan Tanya jawab mengenai hal-hal yang berhubungan dengan materi. Siswa mengerjakan soal postes. Secara bersama-sama siswa membuat kesimpulan hasil belajar.

Dalam melaksanakan perbaikan pembelajaran ini kami dibantu oleh rekan sejawat yang bertindak sebagai pengamat yaitu Ibu Ruchayati. Dengan demikian akan diperoleh data-data yang memang sangat kami butuhkan dalam mengadakan perbaikan pembelajaran ini. Agar pengamatan ini dapat berjalan dengan baik maka kami memulai dari kesepakatan antara pengamat dengan peneliti, hal ini bertujuan agar pengamatan yang dilakukan lebih terarah pada masalah yang akan diamati.

Beberapa aspek yang diamati antara lain, sebagai berikut: Menjelaskan konsep kenampakan alam. Memimpin diskusi kelompok.
Membimbing siswa berdiskusi. Menarik kesimpulan.

Kegiatan siklus 2 selanjutnya adalah refleksi yang berguna untuk menemukan beberapa hal yang telah dilakukan sehingga peneliti dapat diketahui beberapa hal yang menjadi kekuatan dan kelemahan diri yaitu :

Berbagai hal yang menjadi kekuatan atau manfaat antara lain peneliti dapat secara langsung memperbaiki praktik-praktik pembelajaran yang selama ini dilakukan agar menjadi lebih baik dan efektif karena dapat melihat/merasakan/menghayati dan bisa menawarkan cara baru untuk memperbaiki dan meningkatkan profesionalisme guru dalam kegiatan pembelajaran. Dengan cara melihat berbagai indicator keberhasilan proses dan hasil pembelajaran yang terjadi pada siswa.

Validasi PTK ini masih sering dipertanyakan karena metodologi yang agak longgar yang bersifat informal meskipun dijaga keobjektifannya masih menimbulkan keraguan.Hasil penelitian yang dilakukan tidak dpaat digeneralisaskikan karena memang hasil tersebut hanya terkait dengan siswa didalam kelas yang telah disesuaikan dengan situasi dan kondisi yang ada.

Langkah yang ditempuh dalam perbaikan pembelajaran mata pelajaran IPS : Sebagai kegiatan awal guru mengadakan Tanya jawab dengan siswa. Menyajikan materi melalui metode: ceramah dan diskusi dengan siswa. Melakukan pengamatan diluar kelas. Menganalisa LKS. Menarik Kesimpulan. Memberi tugas dan pekerjaan rumah.

Sesuai masalah yang dihadapi yaitu banyaknya siswa yang kurang memahami materi, yang menjadi perhatian khusus dalam perbaikan pembelajaran IPS kelas IV adalah mengupayakan agar siswa dapat termotivasi minat belajarnya.

Analisis data hasil observasi selama proses pembelajaran berlangsung berupa deskriptif kualitatif. Dalam pelakasanaan observasi peneliti dibantu oleh observer untuk mengisi daftar ceklist lembar observasi yang telah disiapkan.Adapun aspek yang diobservasi meliputi keaktifan siswa dalam memperhatikan dan mendengarkan penjelasan guru, bertanya, 
menajwab dan mengemukakan pendapat, serta kegiatan dalam pembelajaran dengan menggunakan metode demonstrasi.

Ketuntasan hasil belajar siswa dapat dilihat dari perolehan skor siswa setelah mengikuti pembelajaran IPA dengan menggunakan netode demonstrasi. Untuk menghitung jumlah skor digunakan pedoman sebagai berikut: $\mathrm{P}=\mathrm{n} \times 100 \%=\mathrm{N}$

Keterangan: $\mathrm{P}=$ Prosentase ketuntasan belajar $\mathrm{n}$ = Jumlah siswa yang tuntas belajarnya $\mathrm{N}=$ Jumlah seluruh Siswa.

\section{HASIL PENELITIAN DAN PEMBAHASAN}

Dalam bab ini akan dipaparkan hasil penelitian dan pembahasan IPS tentang materi Kenampakan Alam melalui model Pembelajaran Interaktif pada siswa kelas IV SD Negeri No. 43 Siguntur Muda Kecamatan Koto XI Tarusan.

Hasil penelitian meliputi tes formatif siswa pada siklus 1 dan siklus 2 , serta hasil penilaian proses yang dilakukan selama berlangsungnya proses belajar mengajar. Peneliti mempersiapkan perangkat pembelajaran yang terdiri dari rencana pelaksanaan pembelajaran, lembar pengamatan, soal-soal formatif, dan alat pembelajaran yang mendukung.
Tahap kegiatan dan pelaksanaan pembelajaran dilaksanakan pada Senin, 8 Juli 2014, di kelas IV (empat) SDN No. 43 Siguntur Muda Kecamatan Koto XI Tarusan dengan jumlah murid 23 orang anak. Peneliti bertindak sebagai guru, observasi/pengamatan dilaksanakan selama proses pembelajaran berlangsung. Proses kegiatan belajar mengajar berpedoman pada RPP yang telah dibuat.

Tes formatif diberikan pada akhir proses pembelajaran, dan tes ini bertujuan untuk mengetahui tingkat pemahaman dan keberhasilan siswa untuk memahami materi yang telah diajarkan.

$\begin{array}{ll}\text { Jumlah Siswa } & : 23 \text { siswa } \\ \text { Jumlah Soal } & : 5 \text { butir } \\ \text { Jumlah nilai maksimal perorangan } & : 100 \\ \text { Jumlah nilai maksimal klasikal } & : 2.300 \\ \text { Ketuntasan yang diharapkan } & : 75 \% \\ \text { Jumlah siswa yang berhasil } & : 13 \text { siswa } \\ \text { Jumlah siswa yang belum berhasil } & : 10 \text { siswa } \\ \text { Prosentase ketuntasan } & : 55 \%\end{array}$

Dari data di atas dapat dijelaskan bahwa siswa yang belum tuntas dalam pembelajaran IPS berjumlah 10 siswa, hal ini disebabkan karena: Siswa belum menguasai materi; Siswa belum menguasai tentang apa yang dijelaskan guru; Siswa belum paham tentang soal yang diberikan guru.

Pada data menunjukkan bahwa secara klasikal siswa belum mencapai ketuntasan belajar, karena siswa yang memperoleh nilai 70 ke atas hanya $55 \%$, lebih kecil dari ketuntasan yang dikehendaki yaitu $75 \%$.

Peneliti mempersiapkan perangkat pembelajaran yang terdiri dari Rencana Pelaksanaan Perbaikan 1, lembar pengamatan, alat evaluasi, scenario pembelajaran tentang Kenampakan Alam, dan alat Pengajaran yang mendukung.

Tahap kegiatan dan pelaksanaan perbaikan pembelajaran dilaksanakan pada Senin, 15 Juli 2014, di kelas IV (empat) SDN No. 43 Siguntur Muda Kecamatan Koto XI Tarusan dengan jumlah murid 23 orang anak. Peneliti bertindak sebagai guru, dan observer yang dilaksanakan selama proses pembelajaran berlangsung. Proses kegiatan belajar mengajar berpedoman pada hasil pembelajaran awal dan pada Rencana Pelaksanaan Perbaikan yang dibuat. 
Tes evaluasi diberikan pada akhir proses pembelajaran, tes bertujuan untuk mengetahui tingkat pemahaman dan keberhasilan siswa terhadap materi yang telah diajarkan.

$\begin{array}{ll}\text { Jumlah Siswa } & : 23 \text { siswa } \\ \text { Jumlah Soal } & : 5 \text { butir } \\ \text { Jumlah nilai maksimal perorangan } & : 100 \\ \text { Jumlah nilai maksimal klasikal } & : 2.300 \\ \text { Ketuntasan yang diharapkan } & : 75 \% \\ \text { Jumlah siswa yang berhasil } & : 16 \text { siswa } \\ \text { Jumlah siswa yang belum berhasil } & : 7 \text { siswa } \\ \text { Prosentase ketuntasan } & : 70 \%\end{array}$

Hasil data di atas dapat dijelaskan bahwa siswa masih belum mampu memahami konsep kenampakan alam berjumlah 7 orang, hal ini menunjukkan adanya peningkatan.Sebelum diadakan perbaikan siswa yang memperoleh nilai diatas 70 hanya 55\%, setelah diadakan perbaikan pertama meningkat menjadi $70 \%$. Meskipun ada peningkatan namun secara klasikal siswa belum mencapai ketuntasan belajar, karena siswa yang memperoleh nilai 70 ke atas masih $70 \%$, lebih kecil dari prosentase ketuntasan yang dikehendaki yaitu sebesar $75 \%$. Pada penilaian proses selama proses pembelajaran masih didapati satu kelompok yang kurang aktif, kerja samanya juga kurang dan waktu menampilkan peran masih kurang serius. Hal ini menunjukkan minat siswa masih kurang.

Pada tahap perencanaan ini peneliti mempersiapkan perangkat pembelajaran yang terdiri dari Rencana Pelaksanaan Perbaikan 2, lembar pengamatan, alat evaluasi, scenario pembelajaran, dan alat Pengajaran yang mendukung.

Tahap pelaksanaan perbaikan pembelajaran dilaksanakan pada Senin, 22 Agustus 2016, di kelas IV (empat) SDN No. 43 Siguntur Muda Kecamatan Koto XI Tarusan dengan jumlah murid 23 orang anak. Peneliti bertindak sebagai guru, dan observer yang dilaksanakan selama proses pembelajaran berlangsung. Proses kegiatan belajar mengajar berpedoman pada hasil perbaikan 1 (siklus 1) dan pada Rencana Pelaksanaan Perbaikan 2 yang telah dibuat.

Tes evaluasi diberikan pada akhir proses pembelajaran, tes bertujuan untuk mengetahui tingkat pemahaman dan keberhasilan siswa terhadap materi yang telah diajarkan.

$\begin{array}{ll}\text { Jumlah Siswa } & : 23 \text { siswa } \\ \text { Jumlah Soal } & : 5 \text { butir } \\ \text { Jumlah nilai maksimal perorangan } & : 100 \\ \text { Jumlah nilai maksimal klasikal } & : 2.300 \\ \text { Ketuntasan yang diharapkan } & : 75 \% \\ \text { Jumlah siswa yang berhasil } & : 20 \text { siswa } \\ \text { Jumlah siswa yang belum berhasil } & : 3 \text { siswa } \\ \text { Prosentase ketuntasan } & : 88 \%\end{array}$

Berdasarkan analisis hasil belajar di atas dapat dijelaskan bahwa siswa yang belum mampu mengerjakan tes evaluasi ada 3 orang, hal ini menunjukkan adanya peningkatan yang signifikan.Sebelum diadakan perbaikan prosentase ketuntasan belajar hanya $55 \%$, setelah diadakan perbaikan 1 meningkat menjadi $70 \%$.Kemudian peneliti melaksanakan perbaikan
2 dengan hasil yang sangat bagus.Prosentase ketuntasan mencapai 88\%, lebih besar dari prosentase ketuntasan yang dikehendaki yaitu sebesar $75 \%$. Pada penilaian proses selama pembelajaran berlangsung sangat terlihat keaktifan siswa, menunjukkan kerjasama baik antara guru dan siswa. 
Berdasarkan hasil penelitian selama proses belajar mengajar berlangsung, menunjukkan adanya peningkatan minat belajar siswa dan hasil belajar siswa pada pembelajaran IPS. Hal ini dibuktikan dengan adanya peningkatan prosentase ketuntasan dalam tes evaluasi pada perbaikan 1 dan tes evaluasi perbaikan 2.Sebelum diadakan perbaikan ketuntasan mencapai 55\% masih jauh dari prosentase ketuntasan yang diinginkan.Tetapi setelah perbaikan 1 prosentase ketuntasan ada peningkatan menjadi 70\%.Meskipun ada peningkatan baik minat maupun hasil belajar siswa pada perbaikan 1 masih perlu perbaikan lagi dikarenakan belum mencapai ketuntasan yang diinginkan.

Kemudian dilakukan perbaikan siklus 2, nilai ketuntasan belajar mengalami kenaikan yang signifikan yaitu 88\%.Dengan demikian pada siklus 2 ini ketuntasan belajar secara klasikal telah tercapai sehingga tidak perlu lagi diadakan perbaikan.Berikut ini grafik hasil perbandingan antara pra siklus, siklus 1 dan siklus 2.

Kemampuan Guru Dalam Mengelola Pembelajaran Berdasarkan hasil penelitian, aktifitas siswa, kerja kelompok dan keseriusan siswa dalam setiap proses pembelajaran mengalami peningkatan, yang berdampak pada peningkatan hasil belajar siswa. Peningkatan hasil belajar siswa menunjukkan seberapa besar peranan guru dalam mengelola pembelajaran, serta guru berhasil menumbuhkan minat siswa terhadap pelajaran Ilmu Pengetahuan Sosial.

Aktifitas Guru Dan Siswa Dalam Pembelajaran Berdasarkan analisis data, dapat diketahui perkembangan aktifitas dalam Proses

\section{KESIMPULAN DAN TINDAK LANJUT}

Pada pra pembelajaran jumlah siswa yang tidak tuntas dalam mengikuti pembelajaran sangat tinggi. Setelah dilaksanakan perbaikan pembelajaran pada Siklus 1 nampak sekali peningkatan hasil belajar siswa yaitu sebesar $70 \%, 16$ siswa sudah tuntas dan 7 siswa masih belum tuntas. Pada siklus 2 mengalami peninkatan secara signifikan sebesar $88 \%$. pembelajaran sebagai berikut. Pada pelaksanaan pembelajaran guru bertanya jawab dengan siswa, guru banyak bercerita sehingga siswa banyak mendengarkan saja, siswa kurang aktif. Pada pelaksanaan perbaikan siklus 1 guru lebih intensif melakukan Tanya jawab dengan siswa, siswa aktif bertanya kepada guru. Guru mengamati siswa dengan menggunakan lembar pengamatan selama siswa mengerjakan tugas. Pada pelaksanaan perbaikan 2, selain melakukan Tanya jawab guru juga menambah media dengan menggunakan gambar kenampakan alam. Siswa lebih aktif dan merasa senang dalam mengikuti kegiatan pembelajaran. Guru mengamati dengan menggunakan lembar pengamatan selama pembelajaran berlangsung.

Guru telah melaksanakan proses pembelajaran dengan baik, diantaranya membimbing, mengarahkan, memberi penguatan/motivasi dan mengamati setiap kegiatan siswa, terutama dalam melakukan Tanya jawab dengan siswa, memotivasi siswa yang kurang berani agar percaya diri. Di akhir pelajaran guru memberikan tes evaluasi.

Hasil penelitian ini menunjukkan bahwa pembelajaran melalui model Pembelajaran interaktif sangat bermanfaat baik bagi guru maupun bagi siswa. Dengan model Pembelajaran interaktif siswa merasa senang karena interaksi dengan guru akan mempermudah dalam memahami materi pelajaran, dapat menghilangkan kejenuhan, rasa bosan dalam pembelajaran. Sehingga penerapan model Pembelajaran interaktif dapat meningkatkan minat siswa dan hasil belajar siswa pada mata pelajaran IPS.

Berdasarkan uraian pembahasan dan hasil penelitian di atas mulai Siklus 1 sampai siklus 2 mengenai penggunaan model pembelajaran interaktif, dapat penulis simpulkan bahwa: 1) Dengan menggunakan pembelc:-....interaktif, ternyata mampu meningk 216 prestasi belajar siswa kelas IV SD Negeri No. 43 Siguntur Muda pada materi tentang kenampakan 
alam. 2) Melalui pembelajaran interaktif, siswa dapat lebih aktif dalam kegiatan belajar, terutama pada mata pelajaran IPS.

Berdasarkan kesimpulan di atas serta hasil perbaikan dan pembelajaran, agar kegiatan belajar mengajar Ilmu Pengetahuan Sosial yang membahas mengenai "Kenampakan Alam" anak lebih aktif, kreatif dan memberikan hasil yang optimal bagi siswa. Maka ada beberapa saran yang dapat disampaikan sebagai berikut: 1) Dalam kegiatan pembelajaran IPS sebaiknya guru menggunakan model pembelajaran interaktif, karena dengan model pembelajaran tersebut dapat meningkatkan prestasi belajar siswa. 2) Guru hendaknya menerapkan pembelajaran interaktif, terutama pada mata pelajaran IPS, karena dapat mengaktifkan siswa dalam pembelajaran

\section{DAFTAR PUSTAKA}

Harlen (1992).Model Pembelajaran Interaktif. London: Kogon Page.

Nanik Budi. (2008). Ilmu Pengetahuan Sosial Kelas IV. Jakarta: Intan Pariwara.

Suciati, (2007).Belajar dan Pembelajaran 2. Jakarta: Universitas Terbuka.

Sudjana.(1990). Prestasi Belajar Siswa. Jakarta: Rineka Cipta.

Sukardi.(1983). Pedoman Penilaian. Jakarta: Rineka Cipta.
Usman.(1999). Penerapan Model Pembelajran Interaktif. Bandung: Pustaka Martina.

Winaputra, S Udin, (2005).Strategi Belajar Mengajar. Jakarta: Universitas Terbuka.

Winaputra, S Udin, (2005).Materi dan Pembelajaran. Jakarta: Universitas Terbuka.

Wardani I.G.A.K, Wihardit Kuswaya, Nasution Noehi. (2006). Penelitian Tindakan Kelas (PTK). Jakarta: Universitas Terbuka. 